\title{
Social Identity of Santri: A Case Study in Politics
}

\author{
Min Hajul Abidin ${ }^{1 *}$, Mustadin ${ }^{2}$ \\ ${ }^{1}$ Southwest University, Chongqing, China \\ ${ }^{2}$ UIN Sunan Kalijaga, Yogyakarta, Indonesia \\ *Corresponding author. Email: minhajulisme@yahoo.com
}

\begin{abstract}
As the largest Islamic organization in Indonesia, the Nahdlotul Ulama (NU) has members (santri) which have contributed to the development of Indonesia. Some of Santri either became politically active as a party member or involved a strategic nonpolitical position. The purpose of the study is to find out how the santri build their social identity in their political activities. A case study was conducted to find the process and the central dynamics of santri in political activities. The several semi-structured interviews were used to obtain the construction of identity of two members of Nahdlotul Ulama (NU) who have grown up in the santri tradition. The results of this research show that a unique identity of santri was built by their pride in their status as santri, since they believe that the santri status has more values than others. They also believe that their political activity is a kind of religious activity.
\end{abstract}

Keywords: santri, identity, strategic, unique, values

\section{INTRODUCTION}

Psychology current reaches various fields of human beings, not only discussing individual behavior (micro) but also discussing human behavior in a broader scope, namely social behavior (macro), such as behavior in groups, human groups are very diverse, such as family, neighborhood, country, religion and so forth. Indonesia is a country with the largest Muslim population in the world. The total is $214,375,487$ (88.2\%) Muslim population in 2010 and is expected to increase to $240,011,944$ Muslim population in 2020 [9]. Santri is one of the informal religion groups in Indonesia. Generally, santri group learns and adheres to thought Ahlussunah Waljama'ah, that identified Nahdlotul Ulama (NU/ The Awakening of Muslim Scholars), the largest Muslim organization in Indonesia [11]. They have a unique characteristic which is different from the student group, that unique characteristic was said by Abdurrahman Wahid as Subculture [16].

The entrance of santri in politics in Indonesia has been seen since the Netherland and Japan colonial era, on early independent until now. The participation of the santri in matters relating to the nation and the state began to appear clear and directed after the establishment of an organization which named itself as The Awakening of Muslim Scholars or more popular with Nahdlatul Ulama [15], for sure this has an impact on santri who are starting to get involved in many political activities. Santri have a long process in politics [17], especially when Indonesian president Abdurrahman Wahid had a background as a santri.

Psychologically the inclusion of santri in political activities, they are experiencing a new social identity, not as a theologian but as practical politicians. The political elite is a small group of people who have a significant influence on the creation and implementation of political decisions [6]. In such conditions, santri involvement changes in social identity. Social identity is "part of an individual's selfconcept that comes from knowing about its membership in a group (groups) social, along with the value and emotional significance." There are the three principles of theoretical. First, members of the Group sought to achieve or maintain a sense of positive social identity. Second, members of the group social identity underlie this benchmarking on good things that can be made between members of the in-group and out-group relevant. Social categories or groups, where individuals become members, provide individuals with a social identity, which allows them to compare their ingroups with relevant out-groups. This benchmarking contributes to an individual's self-esteem because it allows the individual to define and creates the difference that members of their group better than on other groups. Third, members of the group will try to leave their group or join a different, more positive group when their social identity is not satisfactory for them [2].

Social identity is explained as an attraction, caring, proud to be derived from one's knowledge in various categories of social membership with other members, even without the need to have personal relationships that are close, know or have various interests [7]. In addition to Hogg's Social Identity Theory (2002), there are three factors that influence the formation of social identity, namely (a) selfcategorization, (b) social comparison, and (c) interactional models [12].

The santri represented by some of its alumni as politicians also contributed to significant political dynamics in Indonesia. The activities of santri in politics have been recognized in Indonesia, as evidenced by the holding of the National Santri Day (HSN), the Nusantara Santri League (LSN), and several activities carried out by the president, minister or state officials related to the santri. Then how are the psychological dynamics of the santri when they arrive at political activities? And what does the santri mean when they enter into political activities? 


\section{METHOD}

This research was conducted in a different area, namely in the Yogya city and in the Klaten District. The process of data collection is done several times to meet with both subjects, data collection took place at the subject home, in the office of the Provincial Election Commission office in Yogyakarta and Klaten District National Awakening Party. The reason the researchers chose the two subjects was that the subjects had the characteristics needed and appropriate in this study. These characteristics include; is a santri in order of value and is involved in politics. Subject 1 is Chairman of the Branch Management of the Kebangkitan Bangsa Party (PC PKB), NU board member, DPRD member, and Chairman of the Klaten PKB District Faction. Subject 2 is an alumnus of santri and now serves as Commissioner of the Yogyakarta Provincial Election Commission.

This study uses a case study method, with the aim of describing a process or the effect of an event or intervention, especially when the event affects many different parties, in this event related to political activity [10]. The first process is to conduct several interviews with both subjects so that the data is considered sufficient with the data saturation/ similarity. The interview process also involved the closest person to the two subjects (significant others) to deepen the data. The data obtained is classified in stages in the corridors of certain events that are appropriate and influential on the subject.

\section{RESULTS}

After going through several data retrieval, it is known that both subjects have the identity of being santri through processes that are generally:

\subsection{Family}

Both subjects have family backgrounds that uphold the values of santri; since childhood, they have been educated and raised with santri values. Subject 1 came from a family that had a background as a santri, where both parents had a NU ideology, this data was reinforced by data obtained from other significant states that the wife of subject 1 came from a family that had Islamic boarding schools.

"It was the family of my wife, the subject used to live there and then arranged a marriage with his wife, there are still families with families of Islamic boarding schools, and they have strong NU backgrounds (so-2 / w-1 / 146-150)."

In addition, subject one is known to have served in several organizations related to Santri activities, namely NU Board of Pedan District, NU Branch Manager of Klaten Regency, Chairman of the branch leadership board (DPC) of the resurrection party and as the Chairman of the National Awakening Party Faction in Klaten Regency.

Subject 2 is the son of a family who applies santri values. The family of subject 2 has a strong santri (NU) background, both from father and mother. The subject's father had studied Islam in Islamic boarding schools in several places, such as in Jombang Regency and in
Rembang district, his mother had a boarding school background in Jombang district. He admitted that he was a santri who studied religion and had studied in Islamic boarding schools, which made him have values as a santri.

"I grew up in a santri family, my father studied at the Denanyar Islamic Boarding School in Jombang, studying with Mr. KH. Bisri Sansuri continued with Mr. KH. Ahmad then went to study with Mr. KH. Maimun Zubair .... "(w-1 $/ s-2 / 34-35)$

\subsection{Education}

The education process of the two subjects influenced the internalization of the identity they had. Subject 1, while being a student at the university in Semarang district, lives in an Islamic boarding school, here subject 1 strengthens the values of the santri previously obtained. In addition, subject 1 was also active in organizational activities that supported the internalization of values as santri.

Subject 2 has a different experience when he in junior high school (SMP) has continued education in Islamic boarding schools. At the next level at the level of high school (SMA) subject, 2 continue their education in the Islamic boarding school environment. In this process, subject 2 gets more values as santri than before; one of them when subject 2 can get along and have friends from different backgrounds.

"In Tebuireng (Name of Islamic boarding school) I found a variety of people from a variety of ethnicities and various cultures" $(w-2 / s-2 / 168-170)$

\subsection{Political Process}

Both subjects have different political processes. Subject 1 started a career in political activity since at PKB, the subject entered the party's political activities flowing, only following and being active in the organization, the subject having no aspirations to serve as Chairman or member of the subject board termed his natural inclusion in practical politics, adjusting to the existing situation The subject became the Chairman of the PKB PC for several reasons, the subject felt that at that time there were demands of the situation and conditions that required him to become the Chairman of the PKB and to engage in practical politics.

"First, yes politicians just flowed, we followed organizations, were active in organizations, did not have special ideals" (s-1/w-1/47-49)

Subject 1 served several organizational management structures, such as, NU sub-district administrator Pedan, NU district administrator of Klaten district, Chairperson of the Branch Board of the National Awakening Party of Klaten district and member of the Regional Representative Council of Klaten Regency and subject 1 was also Chairman of the district National Awakening Party Faction Klaten.

Subject 2 has a different process in politics; subject 2 has carried out activities that are close to politics since entering the university where subject 2 is the Chairman of the student senate. Subject position 2 is the Election Commission Commissioner, here subject 2 intersects with activities that are very close to practical politics. The subject also 
accommodates the general election participants, which, according to the subject, have the useful experience, because according to the subject, the position as Commissioner of the Election Commission is very strategic. "... The KPU has an effort to explore and enrich the experience while at the same time taking the side of the experience of benefits that I feel are very strategic" ( $w-2$ / $s-2 / 270-274)$

\section{DISCUSSIONS}

Both subjects have family backgrounds, education, and santri organizations. Subject 1 had once served as a board member at $\mathrm{Al}$ Munawir Islamic Boarding School in Semarang, and subject 1 was also alumni in PMII organization. The wife of subject 1 is also a family of Islamic Boarding Al Munawir Semarang. The Gait of subject 1 in the organization was NU organization from subdistrict level to district and the Kebangkitan Bangsa Party (PKB).

The subject 2 has a strong santri's background. Her father and mother were santri. The family's traditions taught to subject 2 was santri's traditions. The education of subject 2 always related to boarding school (Pesantren). The informal education was taught by his father while formal education in elementary school, junior high school, and senior high school obtained in boarding school (Pesantren). When subject 2 entered university, he joined the PMII organization (according to subject 2 this organization has traditions as santri's traditions). The statement of the subject regarding the PMII organization in accordance with what was conveyed by Sayuti et al. (2018), PMII was an organization formed by NU to assist in the NU political movement, especially during the Guided Democracy (President Soekarno) [14].

The search for identity as students in both subjects through cognitive processes. The psychosocial stage between childhood and adulthood, and among the moralities learned by children and ethics that will be developed by adults. This is an ideological mind and ideological hope about a society that speaks clearly to adolescents who wish to be affirmed by their peers and are ready to be confirmed by various rituals, statements of belief and programs at the same time defining what is evil, strange and contradictory [5]. Both of them have Nahdlotul Ulama santri's ideology. The second crisis of the subject in his identity occurred during the period following the organization related to santri and began to understand himself to do a positive evaluation.

The next process that occurred in both subjects was that they believed that they were part of a group of santri, both of whom were very proud to be part of the santri group. Both also have initiatives in raising groups of santri with a different strategy.

Social identity is part of an individual concept that comes from understanding membership in a social group or group together with emotional meaning in-group members [4], individual social identity is in fact formed by both group factors and individual factors, two models that can explain the process, namely through the process of induction (Bottom-up) and deduction (top-down). The induction model describes the process of forming social identity from an individual's point of view. This process is simply understood when individuals have realized the importance of their social relations with group members, with a consensus that has been understood together. The second model is deduction (top-down). This model emphasizes group function as an individual's social identity.

That groups already have and serve certain attributes and values that are in groups that bind their members into a collective unit [1]. It can be concluded that both models of social identity formation are, in fact, inseparable from each other. This process is complimentary. When examined further, they have formed a circular chain that is difficult to identify again, which is the beginning and the end [1]. Both subjects were indeed brought up in the Nahdliyin tradition, but this would not have an effect if neither of them knew their respective roles as santri in the political sphere. The formed of awareness is through a long process of the life journey of both subjects.

Individuals need for order in the social environment. As a result, individuals put themselves around in the social category that defines it as group membership. However, a group can only exist if it is defined in traits that are specific to other groups and only able to maintain its identity if the group maintains meaningful existence from other groups. This is related to sharp differences in in-group relations that lead to in-group and out-groups bias, where groups tend to sharpen differences between them in forming positive uniqueness, while bias in groups influences the perception of relationships between groups and the interaction of several relationships seems to be a factor that reinforces these conditions [7].

Many of our social behaviors can be explained by our tendency to identify ourselves as part of a group and to judge others as part of that group or not. That is, at this stage, there is a firm assessment of other people as part of 'us' or part of 'them.' Although the form of groups that we consider to be our group will vary greatly according to the personal experience and culture that we occupy, the tendency to consider ourselves as part of one or several groups is universal. With the development of these mechanisms, there is a tendency to side with groups that support cooperation and help us in shaping society [8]. Group behavior is different from individual behavior, which includes group behavior, including ethnocentrism, in-group bias, intergroup competition and discrimination, stereotypes, prejudice, integrity, conformity, and group cohesiveness. A person's social identity contributes to selfconcept and allows the person to place himself in a certain position in a complex network of social relations [13]. Groups that are members are called in-groups, and groups that are not members are called out-groups [2].

The above theory is in accordance with that experienced by both subjects. Subject 1 felt that other parties always used the santri group at certain moments and did not fight for santri consistently, according to him, it had happened since a long time ago. Subject 2 felt the New Order (President Soeharto) was a figure of an authoritarian regime with Abrinya. Both subjects, basically has discrimination experienced as santri in politics. The findings in this study are the same as the findings in other studies, which state that identity plays an important role in discriminatory behavior 
[3] as did the two subjects, who always gave a positive value to the identity of the group.

Both of them position themselves as santri, who occupy strategic positions. Both of them assumed that his position was either subject 1 as a member of the Regional People's Representative Council (DPRD) and subject 2 as the Commissioner of the General Election Commission (KPU). They felt more valuable than their other counterparts who were not santri.

Both of subjects conducted positive evaluations, related to the current position of the santri. Subject 1 is of the view that santri, have to master in classical Islamic knowledge, and must be master technology. In politics, according to subject 1 , it is mandatory with Kebangkitan Bangsa Party (PKB), because PKB has always fought for the santri. Subject 2 has the view that santri is time to fill the country's strategic posts, not only concentrated in one field. The subject saw that if these strategic posts were not controlled by good people (santri), it would be dangerous.

When dealing with other groups in politics, the two subjects put forward the values that are considered the characteristics of santri. Subject 1 is raising Nahdlotul Ulama (NU) with the National Revival Party (PKB) path as a way of worship, which is always asking the Kiai's opinion as a reference. Subject 2 applies the values of santri at the level of General Election Commissions (KPU) commissioners with Fiqh reasoning, and Subject 2 positioned himself as Khodamul Ummah.

\section{CONCLUSION}

Based on the findings through interview and observation methods and through the process of data processing in this study, the process of the social identity of the two subjects is not the same, but in general, the two subjects have the same goal of raising groups they are proud of, namely the santri.

The development of identity as a santri is formed from the family background; both of them are santri. Furthermore, the two subjects increasingly embedded the identity as santri through education, especially in boarding schools. The values of identity as santri both subjects can be applied when both of them enter the professional activities, in this case, is politics. Subject 1 understood his identity as a Regional People's Representative Council (DPRD), which fought for santri as a way of worship, and subject 2 interpreted his identity as Commissioner of the General Election Commission (KPU) as Khodamul Ummah.

Subsequent research requires examples and experiences from students who are involved in more complex political activities, for example santri who are included in other parties such as Golkar, Nasdem, PDI-P, Gerindra, etc. or santri who are active in political activities outside parties such as the Regional Leadership Council (DPD) and increasing the number of subjects with different party backgrounds will produce more complex results. In addition, research on the identity of santri in political activities requires more identification and development through a multidisciplinary understanding of science and methods.

\section{REFERENCES}

[1] Afif, A. (2015). Teori identitas sosial. In: Yogyakarta: UII Press.

[2] Cottam, M. L., Dietz-Uhler, B., Mastors, E., \& Preston, T. (2012). Pengantar psikologi politik = Introduction to political psychology. Jakarta: Rajawali Pers.

[3] Daskalova, V. (2018). Discrimination, social identity, and coordination: An experiment. Games and Economic Behavior, 107, 238-252.

[4] Ellemers, N., \& Haslam, S. A. (2011). Social identity theory. Handbook of theories of social psychology, 2(2011), 379-398.

[5] Erikson, E. H. (2010). Childhood and Society. Yogyakarta: Pustaka Pelajar.

[6] Haryanto, H. C., \& Rahmania, T. (2015). Bagaimanakah Persepsi Keterpercayaan Masyarakat terhadap Elit Politik? Jurnal Psikologi, 42(3), 243-258.

[7] Huda, M. J. N. (2012). Teori psikologi sosial makro. Yogyakarta: Ash-Shaff.

[8] Jarvis, M. (2015). Teori-teori psikologi pendekatan modern untuk memahami perilaku, perasaan dan pikiran manusia. Bandung: Nusa Media.

[9] Kettani, H. (2010). Muslim population in Asia: 1950-2020. International Journal of Environmental Science and Development, 1(2), 143.

[10] Kohn, L. T. (1997). Methods in case study analysis: Center for Studying Health System Change Washington, DC.

[11] Niam, K. (2017). Nahdlatul ulama and the production of muslim intellectuals in the beginning of 21 st century indonesia. Journal of Indonesian Islam, 11(2).

[12] Putri, K. (2013). Hubungan Antara Identitas Sosial Dan Konformitas Dengan Perilaku Agresi Pada Suporter Sepakbola Persisam Putra Samarinda. eJournal Psikologi. E Journal Psikologi, 1(3), 241-253.

[13] Sarwono, S. W. (1999). Psikologi Sosial Psikologi Kelompok dan Psikologi Terapan. Jakarta: Balai Pustaka.

[14] Sayuti, A., Wasino, W., \& Sodiq, I. (2018). Dinamika Politik Partai Nahdlatul Ulama Di Semarang Tahun 1952-1979. Journal of Indonesian History, 7(1), 1-11. 
[15] Syaiful, M. (2005). Politik Kiai dan Implikasinya Terhadap Politik Santri (Studi Kasus Pondok di

Kaliwungu Kendal). Semarang: UIN Walisongo.

[16] Wahid, A., \& Rahardjo, M. D. (1988). Pesantren dan pembaharuan: Lembaga Penelitian, Pendidikan dan Penerangan Ekonomi dan Sosial.

[17] Yusuf, S. E., Syam, M. I., \& Masudi, M. F. (1983). Dinamika kaum santri: menelusuri jejak \& pergolakan internal NU: Rajawali. 